\title{
TRANSMISI HUKUM EKONOMI SYARIAH DI RUANG DIGITAL (KAJIAN TERHADAP AKUN INSTAGRAM @MUAMALAH_DAILY)
}

\author{
Riska Fauziah Hayati
}

UIN Sunan Kalijaga Yogyakarta

e-mail: riskafauziahhayati@gmail.com

\begin{tabular}{|l|l|l|} 
Submit: 18-02-2021 & Direvisi: 09-04-2021 & Dipublish: 26-06-2021
\end{tabular}

Abstract: Nowadays, users of mobile devices are experiencing in increase. Likewise in accessing various social media, one of which is Instagram. Instagram provides various features to disseminate information that supports the fulfillment of people's information needs. Like the instagram account@muamalah_daily as a medium for transmission muamalah. This paper intends to explore what kind of Islamic economic law discourse is represented by the Instagram account@muamalah_daily, as well as how the discourse is constructed. To answer these questions, the approach used in this study was content analysis. This paper found that Islamic economic law represented in the@muamalah_daily account is dominated by contextual contemporary muamalah fiqh while still paying attention to the basic concepts of classical figh. The discourse is constructed in light language that easily understood by the public, and is packaged in an attractive appearance.The@muamalah_daily account is also flexible and systematic in responding to contemporary practices. Along with the times, the practice of sharia economic law is increasingly diverse; many people are still taboo about the law. In this condition, society needs legal knowledge about contemporary economic practices that are still new. Thus, the @ muamalah_daily account indirectly influences the Islamic economic law discourse that develops in society.

Kata kunci: Tranmisi, Hukum Ekonomi Syariah, Akun@muamalah_daily.

\section{PENDAHULUAN}

Pengguna smartphone atau ponsel meningkat. Pada tahun 2018 lebih dari setengah jumlah penduduk di Indonesia atau 56,2 \% telah menggunakan smartphone. Setahun setelahnya, masyarakat pengguna smartphone mencapai 63,3 \%. Hingga tahun 2025, pengguna smartphone setidaknya mencapai 89,2 \% dari populasi di Indonesia (Databoks, 2020). Meningkatnya pengguna smartphone tentunya berdampak terhadap meningkatnya pengguna media sosial, salah satunya instagram. Persentase pengguna instagram di Indonesia pada tahun 2020 mencapai $79 \%$ dari jumlah populasi, yaitu sebanyak 63 juta jiwa penududuk Indonesia menggunakan instagram. Angka tersebut merupakan peningkatan dari bulan ke bulan. Platform instagram menempati posisi keempat setelah facebook dengan persentase $82 \%$. Urutan satu dan dua ditempati oleh youtobe dengan persentase $88 \%$ dan whatsapp 84 \% (Andilink, 2020). Tak bisa dipungkiri bahwa instagram merupakan salah satu platform yang paling digemari.

Instagram dapat digunakan baik untuk kepentingan pribadi, korporasi, maupun sebagai media iklan merek dagang tertentu. Selain itu, instagram juga digunakan sebagai media transmisi informasi untuk kalangan tertentu (GoodNews From Indonesia, 2020). Pengguna instagram didominasi oleh milenial, dan jika dilihat lebih lanjut pengguna instagram didominasi oleh 
perempuan (Nisa, 2018: 68-69). Kehadiran internet telah memudahkan akses dalam proses pembelajaran. Jika sebelumnya seseorang harus keluar masuk perpustakaan untuk mencari informasi atau bahan belajar, sekarang seseorang hanya butuh jaringan internet untuk mengakses informasi kapan saja dibutuhkan (Sesriyani \& Sukmawati, 2019). Dalam hal ini instagram juga ikut mengambil peran.

Instagram merupakan salah satu media sosial dimana pengguna tidak hanya sebagai pembaca tetapi juga pembuat konten. Sebagaimana menurut Evans, media sosial merupakan demokratisasi informasi, dari yang sebelumnya sebagai pembaca konten, berubah menjadi penerbit konten. Hal ini adalah hasil dari pergeseran mekanisme siaran dari sebuah model ke banyak model, berawal dari percakapan antara peneliti, orang dan rekan-rekan (Arifin, 2015: 3972).

Semakin berkembangnya zaman, instagram dipandang cukup dalam mempengaruhi pengetahuan masyarakat. Instagram yang awalnya hanya digunakan sebagai media berkomunikasi masyarakat, saat ini telah digunakan untuk berbagai kegiatan, seperti untuk bisnis, bahkan untuk menyebarkan pengetahuan. Beberapa pegetahuan ditransmisikan melalui instagram. Sehingga, instagram sebagai pembawa wacana dengan transmisi dapat mempengaruhi cara berpikir maupun cara bertindak seseorang (Eriyanto, 2001: 65).

Tren instagram ini mendorong untuk semangat belajar dengan independen, instan dan juga tersedia berbagai informasi tanpa batas (Dahlan, 2020: 16). Hal ini menjadi daya tarik sendiri bagi orang-orang untuk mencari konten pengetahuan dalam instagram karena akses yang mudah dan menarik di tengah sulitnya untuk mengakses kajiankajian klasik. Pemanfaatan media sosial sebagai suatu cara dalam penyebaran agama dianggap berhasil dalam menyebarkan pesan-pesan Islam (Zahara et al., 2020: 60-61). Salah satu pengetahuan yang tersebar di beberapa akun instagram adalah fikih muamalah. Dalam hal ini, instagram berfungsi sebagai media transmisi ilmu seputar hal-hal yang berkaitan dengan hukum ekonomi syariah.

Minimnya akses masyarakat terhadap kitab-kitab muamalah klasik diiringi dengan banyaknya media sosial yang aktif membicarakan persoalan muamalah. Belakangan ini, banyak akun instagram yang mempublikasikan informasi seputar hukum ekonomi syariah, di antaranya akun @muamalah_daily, @muamalah.muslimah, @fikihmuamalatkontemporer, @muamalatdin, @ngajimuamalah, @muamalahid, @sudutmuamalah, @fikihpengusaha dan masih banyak lagi. Adapun akun instagram yang penulis pilih dalam penelitian ini adalah @muamalah_daily. Akun yang dikelola oleh Ustadz Dr. Oni Sahroni, M.A., ini telah mempunyai pengikut sekitar 20,3 ribu dan tidak kurang dari 852 postingan.

Akun instagram @muamalah_daily selalu aktif dalam berbagi informasi seputar muamalah (hukum ekonomi syariah) dan juga membuka konsultasi syariah. Di antara program yang ditawarkan akun@muamalah_daily adalah Muamalah Kekinian, Bedah Istilah, Quiz Fikih, Ini Dulu Baru Itu, Live 
Konsultasi Syariah, Tips Muamalah, Kata Ustadz, 1 Minute Booster, Serial Merawat Iman, Alhamdulillah I Know, Tanya Ustadz, Live SERUM (Sekolah Ekonomi Rumah Tangga Muslim), Bedah Fikih Kekinian, Mutiara Fikih, dan Serial Jawab Kuis. Akun @muamalah_daily juga berbagi buku-buku seputar syariah dan fikih muamalah serta jadwal dan kegiatan-kegiatan yang dilakukan oleh Oni Sahroni. Sehingga, para followers @muamalah_daily dapat memperoleh informasi seputar hukum ekonomi syariah dengan mudah. Dalam setiap postingan yang di-upload oleh @muamalah_daily mendapatkan banyak tanggapan positif oleh para pengikutnya, dengan memberikan tanda love pada postingan maupun tanggapan pada kolam komentar. Dengan demikian, konstruksi wacana hukum ekonomi syariah yang berkembang di masyarakat akan dipengaruhi oleh ideologi yang ditampilkan oleh akun @muamalah_daily.

Kajian ilmiah mengenai transmisi hukum ekonomi syariah di ruang digital sejauh ini masih sangat minim. Sebelumnya, studi hukum ekonomi syariah cenderung kepada persoalan praktek-praktek muamalah kontomporer, terutama praktek muamalah yang terjadi di era digital. Berdasarkan ulasan tersebut, penulis mencoba mengkaji muamalah dari sisi yang berbeda, yaitu bagaimana transmisi hukum ekonomi syariah di ruang digital khususnya pada akun@muamalah_daily.

\section{METODE PENELITIAN}

Dalam penelitian ini penulis menggunakan penelitian kualitatif dengan pendekatan analisis konten. Penelitian ini bersifat deskriptif-analitis. Adapun yang ingin penulis analisis adalah bagaimana peran ruang digital sebagai media transmisi pengetahuan hukum ekonomi syariah dan wacana hukum ekonomi syariah seperti apa yang direpresentasikan oleh akun instagram @muamalah_daily, serta bagaimana wacana tersebut dikonstruksi. Adapun konten-konten dari akun @muamalah_daily yang penulis kaji adalah Muamalah Kekinian, Bedah Istilah, Quiz Fikih, Ini Dulu Baru Itu, Live Konsultasi Syariah, Tips Muamalah, Kata Ustadz, 1 Minute Booster, Serial Merawat Iman, Alhamdulillah I Know, Tanya Ustadz, Live SERUM (Sekolah Ekonomi Rumah Tangga Muslim), Bedah Fikih Kekinian, Mutiara Fikih, dan Serial Jawab Kuis. Jawaban atas pertanyaan tersebut akan menjadi pokok bahasan tulisan ini.

\section{TRANSMISI MELALUI INSTAGRAM \\ PENGETAHUAN MEDIA SOSIAL}

1. Media Sosial Instagram

Sosial media adalah sebuah media online, dimana para user melalui aplikasi berbasis internet dapat berbagi, berpartisipasi, dan menciptakan konten berupa blog, forum, jejaring sosial, wiki, dan ruang virtual yang didukung oleh teknologi multimedia yang canggih (Tim Penyusun Humas Kementerian Perdagangan RI, 2014: 25). Media sosial merupakan wadah yang bisa menciptakan berbagai bentuk komunikasi dan berbagi berbagai informasi (Ferlitasari, 2018: 2).

Ciri-ciri media sosial menurut Tim Pusat Humas Kementrian Perdagangan RI, sebagaimana tertera dalam karyanya berjudul Panduan Optimalisasi Sosial 
adalah sebagai berikut (Ferlitasari, 2018: 27):

a. Konten yang disampaikan dibagikan kepada banyak orang, artinya tidak terbatas pada satu orang tertentu.

b. Isi pesan muncul tanpa gerbang penghambat (gatekeeper).

c. Isi disampaikan secara online dan langsung.

d. Konten diterima secara online dalam waktu lebih cepat dan juga bisa tertunda penerimaannya tergantung pada waktu interaksi yang ditentukan oleh pengguna.

e. Penggunanya sebagai kreator dan aktor.

f. Di dalam kontennya terdapat sejumlah aspek fungsional seperti identitas, percakapan (interaksi), berbagi (sharing), kehadiran (eksis), hubungan (relasi), reputasi (status) dan kelompok (group).

Pendapat lain mengatakan karakteristik media sosial adalah adanya jaringan (network), informasi (information), arsip (archive), interaktivitas (interactivity), simulasi sosial (social simulation) dan konten pengguna (user-generated content) (Nasrullah, 2015: 48).

Media sosial memiliki banyak manfaat dan kegunaan, di antaranya adalah sebagai media interaksi sosial, media penyebaran informasi dan media usaha. Sebagaimana diungkapkan Haryanto, menggunakan media sosial sebagai sarana penyebaran informasi dan interaksi sosial merupakan langkah efektif karena interaksinya tidak terbatas hanya untuk individu dan informasi juga dapat diperoleh dengan cepat (Haryanto, 2016: 83-86). Pengguna dapat mengakses kapanpun dan dimanapun hanya dengan koneksi internet.
Salah satu media sosial yang banyak digunakan adalah instagram. Nama instagram berasal dari pengertian keseluruhan fungsi aplikasi ini. Kata "insta" berasal dari kata "instan", seperti kamera polaroid yang pada masanya dikenal dengan "foto instan". Sedangkan kata "gram" berasal dari kata "telegram", dimana telegram sendiri berfungsi untuk mengirimkan informasi kepada orang lain dengan cepat (Aditya, 2015: 3). Begitu juga instagram yang memungkinkan pengguna menggugah foto dengan cepat menggunakan jaringan internet.

Instagram merupakan sebuah aplikasi berbasis android yang memungkinkan penggunanya untuk mengambil foto, menerapkan filter digital, dan membagikannya ke berbagai layanan jejaring social (Agustina, 2016: 412). Instagram menjadi salah satu platform media sosial terbesar di dunia. Berdasarkan data yang diambil dari We are Social, Houtsuite, pada tahun 2019, lebih dari satu miliar pengguna aktif instagram di seluruh dunia. Indonesia menempati posisi keempat pengguna instagram terbanyak di seluruh dunia, setelah Amerika Serikat, India dan Brasil (Lokadata, 2019). Di Indonesia, pengguna instagram didominasi oleh golongan usia produktif, dalam rentang usia 18 sampai 34 tahun, yang lazim disebut generasi milenial (GoodNews From Indonesia, 2020).

Adapun kelebihan instagram antara lain adalah (Makhin, 2016: 43-45):

a. Untuk menggunakan instagram tidak perlu membayar, cukup dengan mengunduh dan dapat juga langsung membuka situsnya. Berbeda dengan menggunakan webiste yang harus menyewa domain dengan biaya yang bervariasi. 
b. Banyak digunakan. Pengguna instagram setiap tahunnya mengalami peningkatan. Hal ini karena media instagram dapat dimiliki oleh setiap orang.

c. Mudah digunakan. Memposting foto atau video, memfollow, mengomentri, memberi tnda suka hingga mencari hastag dapat dilakukan dengan mudah.

d. Mudah dalam melakukan berbagai promosi. Misalnya, dengan menggunakan hastag, jasa endorsement atau dengan paid promote.

e. Media utama berupa foto, dengan kualitas dan tampilan yang baik.

f. Koneksi dengan media sosial lain.

\section{Instagram dan Transmisi Pengetahuan}

Seiring berkembangnya ilmu pengetahuan dan teknologi di era globalisasi, telah menjadikan media sosial memiliki banyak kegunaan dan pemanfaatan. Menurut Ninok Leksono karakteristik teknologi informatika dan komunikasi telah memanjangkan dan meluaskan manusia. Bukan kaki dan tangan manusia, melainkan daya pikir dan keseluruhan akal budinya (Sari, 2017: 7).

Saat ini fitur instagram tidak terbatas pada interaksi sosial, berbagi foto, dan video. Tetapi fitur-fitur instagram pada umumnya lebih dari itu, antara lain (Adalah.Co.Id, 2019):

a. Interaksi antar pengguna instagram. Ini merupakan fungsi utama dari aplikasi media sosial. Sebelumnya interaksi spesifik instagram dapat melalui berbagi foto, video dan mengirim pesan (DM). Selain itu, ada juga fitur perekaman langsung atau fitur insta story, yang memungkinkan untuk berbagi kegiatan sambil berinteraksi dengan teman-teman yang menontonnya. Konten yang diunggah di cerita instagram akan menghilang setelah 24 jam. Pada tahun 2018 instagram juga meluncurkan fitur IGTV. IGTV memungkinkan unggahan dengan durasi 10 menit dan ukuran file hingga $650 \mathrm{MB}$, dan untuk pengguna yang diedit dan popular dapat menggugah video hingga 60 menit dan ukuran file hingga 5,4 GB.

b. Mencari dan berbagi informasi. Di antara banyaknya pengguna instagram, ada akun non-pribadi atau pribadi dengan informasi tertentu atau keahlian di bidang tertentu. Instagram dijadikan sebagai tempat untuk melakukan aktivitas berbagi ilmu, bersosialisasi, bertukar informasi dan pada intinya berbaur dan bergabung dengan orang lain. Menggugah video juga dapat digunakan untuk berbagi informasi.

c. Sebagai sarana pemasaran. Saat ini, banyak pelau bisnis atau penjual produk yang menggunakan pemasaran online, salah satunya di instagram.

Kehadiran media sosial juga menjadi pendorong untuk memaksimalkan pembelajaran menjadi lebih menyenangkan, dengan menyediakan pilihan konten-konten positif di tengah beragamnya informasi yang ada. Menurut Mudhofir sebagaimana yang dikutip Meutia menyatakan bahwa yang termasuk sumber belajar adalah berbagai informasi, data-data ilmu pengetahuan, gagasan-gagasan manusia, baik dalam bentuk bahan-bahan tercetak maupun non cetak (Sari, 2017: 7). 
Informasi dibutuhkan sebagai bagian dari tuntutan kehidupan seseorang, dalam penunjang kegiatan dan pemenuhan kebutuhan. Setidaknya sebagai data dan fakta yang membuktikan adanya suatu kebenaran, untuk penjelas hal-hal yang sebelumnya meragukan. Informasi adalah data yang diolah menjadi bentuk lebih berguna, lebih berarti dan bermanfaat bagi penggunanya (Arifin, 2015: 3974).

Data merupakan suatu gambaran kejadian dan kesatuan yang nyata. Data juga dapat diartikan sebagai representasi dunia nyata yang mewakili suatu objek tertentu seperti manusia, hewan, konsep, peristiwa, keadaan dan hal-hal lain yang direkam kedalam bentuk angka, huruf, teks, simbol, gambar, suara, atau kombinasi dari keseluruhan. Sebelumnya, data yang berkualitas diolah melalui suatu model pengolahan data atau dikenal dengan siklus pengolahan data (siklus informasi) (Arifin, 2015: 3974).

Guha sebagaimana dikutip Helen dan Farid dalam jurnalnya, menjelaskan beberapa jenis pendekatan kebutuhan terhadap informasi pengguna media social (Helen \& Rusdi, 2019: 357-358):

a. Current need approach, yaitu pendekatan terhadap kebutuhan pengguna informasi yang bersifat mutakhir. Pengguna berinteraksi dengan sistem informasi dengan cara yang sangat umum untuk memperluas pengetahuannya. Sehingga perlu adanya interaksi yang konstan antara pengguna dengan sistem informasi.

b. Everyday need approach, yaitu pendekatan terhadap kebutuhan pengguna yang membutuhkan informasi secara spesifik, cepat dan rutin. c. Exhaustic need approach, yaitu pendekatan terhadap kebutuhan pengguna akan informasi yang mendalam, pengguna informasi mempunyai ketergantungan yang tinggi pada informasi yang dibutuhkan dan relevan, spesifik dan lengkap.

d. Catching-up need approach, yaitu pendekatan terhadap pengguna akan informasi yang ringkas, lengkap dan terbaru serta hal-hal yang sifatnya relevan.

\section{TRANSMISI HUKUM EKONOMI SYARIAH DALAM AKUN @MUAMALAH_DAILY}

\section{Gambaran Umum Akun Instagram @muamalah_daily}

Akun instagram @muamalah_daily adalah sebuah akun yang berisi konten informasi seputar hukum ekonomi syaraih (muamalah), akun ini juga membuka konsultasi syariah dan muamalah, disertai foto dan video berisi visual dan audio. Akun ini diasuh oleh Ustadz Dr. Oni Sahroni, M.A., yang merupakan anggota Dewan Syariah Nasional Majelis Ulama Indonesia. Selain itu, ia juga seorang Pengasuh Talaqqi Fikih Muamalah SEBI, Pengasuh Konsultasi Syariah di akun @muamalah_daily dan Republika. Ia merupakan lulusan Doktoral Universitas Al-Azhar Kairo pada tahun 2009, dengan spesialisasi fikih muamalah. Ia telah menulis beberapa buku, di antaranya: Ini Dulu Baru Itu; Fikih Muamalah Kontemporer; Riba, Gharar dan KaidahKaidah Ekonomi Syariah; Maqashid Bisnis dan Keuangan Islam; Fikih Muamalah; 


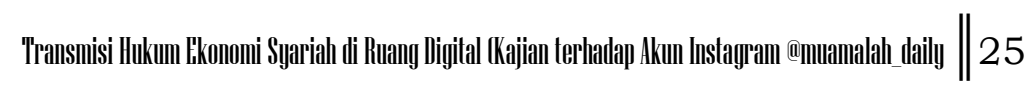

Ushul Fikih Muamalah; Fikih Zakat Kontemporer, dan masih banyak lagi.

Berbeda dengan akun-akun instagram lainnya yang hanya berbagi informasi mengenai muamalah, akun @muamalah_daily hadir dengan cara berbeda. Tidak hanya sekedar berbagi informasi, akun ini juga membuka konsultasi syariah dan muamalah bagi masyarakat yang ingin berkonsultasi langsung. Selain itu, akun @muamalah_daily juga acap kali mengadakan siaran langsung interaktif dengan followersnya.

Postingan pertama akun ini adalah pada Juli 2017. Pada awalnya, akun @muamalah_daily berisi kegiatankegiatan yang dilakukan oleh Oni Sahroni, baik kajian-kajian fikih muamalah, seminar dan pelatihanpelatihan yang diisi oleh Oni Sahroni. Pada Desember 2017, barulah akun ini membagikan tentang tanya jawab fikih muamalah. Saat ini, akun @muamalah_daily telah memiliki 20,3 ribu pengikut dan sudah memposting sekitar 852 post per tanggal 12 Desember 2020.

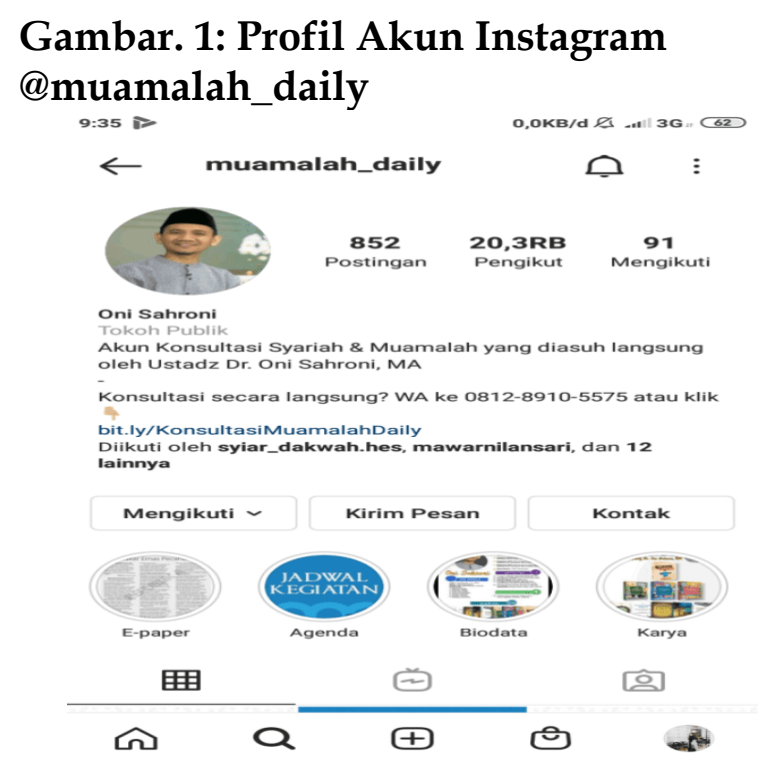

\section{Representasi Hukum Ekonomi Syariah pada Akun @muamalah_daily}

Akun@muamalah_daily membagikan informasi seputar hukum ekonomi syariah dengan berbagai postingan yang kreatif. Akun ini merepresentasikan hukum ekonomi syariah dengan menawarkan beberapa program yang bisa dimanfaatkan oleh para pengikutnya. Umumnya, konten yang diposting didominasi oleh fikih muamalah kontemporer, dengan merujuk kepada konsep dasar fikih klasik. Di tahun 2020, akun @muamalah_daily menawarkan program-program baru, di antaranya adalah Muamalah Kekinian, Bedah Istilah, Quiz Fikih, Ini Dulu Baru Itu, Live Konsultasi Syariah, Tips Muamalah, Kata Ustadz, 1 Minute Booster, Alhamdulillah I Know, Live SERUM (Sekolah Ekonomi Rumah Tangga Muslim), Bedah Fikih Kekinian, Mutiara Fikih, dan Serial Jawab Kuis. Akun @muamalah_daily juga memposting buku-buku tentang syariah dan fikih muamalah serta jadwal dan kegiatankegiatan yang dilakukan oleh Oni Sahroni. Berikut tampilannya:

Muamalah Kekinian merupakan salah satu content dari @muamalah_daily yang menjelaskan konsep muamalah yang disesuaikan dengan konteks kekinian. Dengan kata lain porgram ini adalah program yang membahas isu-isu terkini persoalan muamalah, seperti bisnis online, saham, dan sebagainya. Oni menjawab pertanyaan-pertanyaan tentang persoalanpersoalan muamalah terkini dengan mengemukakan dalil-dalil dan hukum terkait serta menganalisanya sesuai dengan konteks saat ini.

Gambar. 2: Program Muamalah Kekinian 


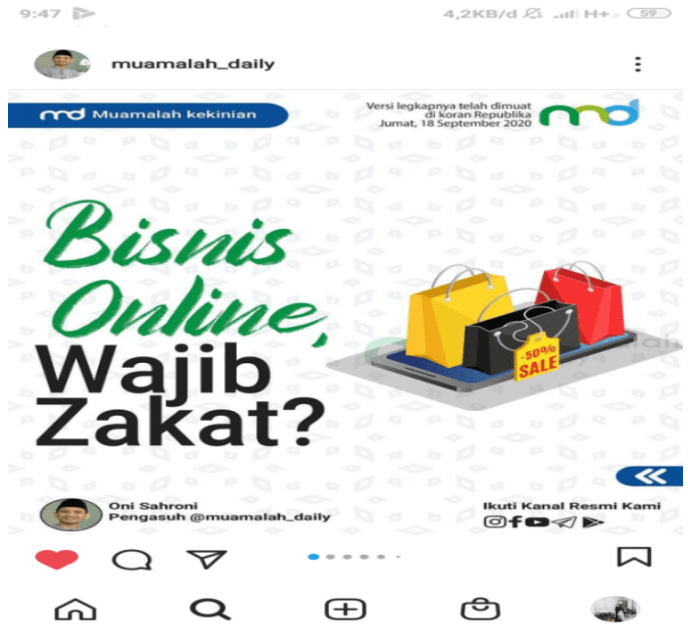

Bedah Istilah merupakan content dari @muamalah_daily untuk menjelaskan istillah-istilah tertentu yang berkaitan dengan syariah dan muamalah. Oni mencoba menjelaskan dengan mudah dan ringkas tentang konsep-konsep dan istilah-istilah dasar muamalah, seperti hamisy jiddiyah atau uang muka.

\section{Gambar. 3: Program Bedah Istilah}

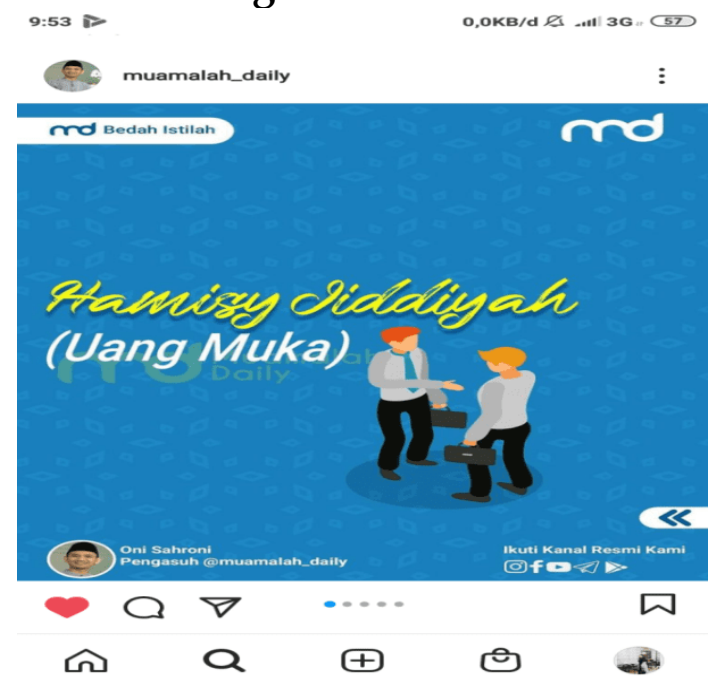

Quiz Fikih merupakan program dari @muamalah_daily untuk memberikan tantangan sederhana kepada para followers berupa pertanyaan-pertanyaan tentang muamalah. Dalam program ini, Oni memberikan kuis kepada pengikut berupa pertanyaan-pertanyaan. Para pengikut menjawab di kolom komentar, kemudian dikoreksi oleh Oni, dan bagi jawaban yang benar pada umumnya diberikan hadiah berupa buku.

\section{Gambar. 4: Program Quiz Fikih}

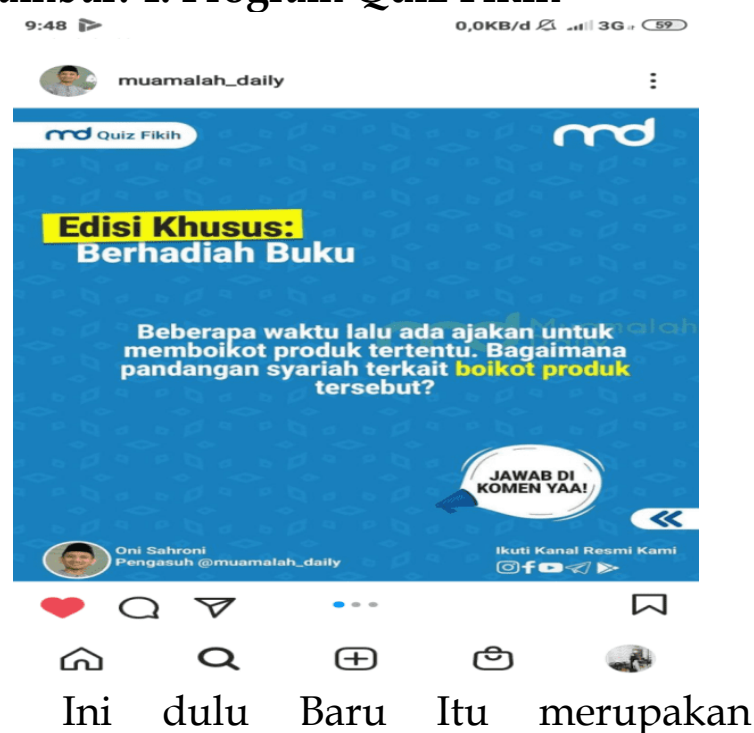
program untuk memahami fikih proiritas dengan lebih praktis. Program ini diadaptasi langsung dari karyanya Oni Syahroni yang berjudul "Ini Dulu Baru Itu".

\section{Gambar. 5: Program Ini Dulu Baru Itu

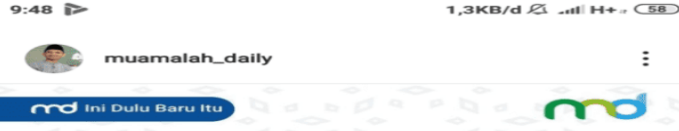

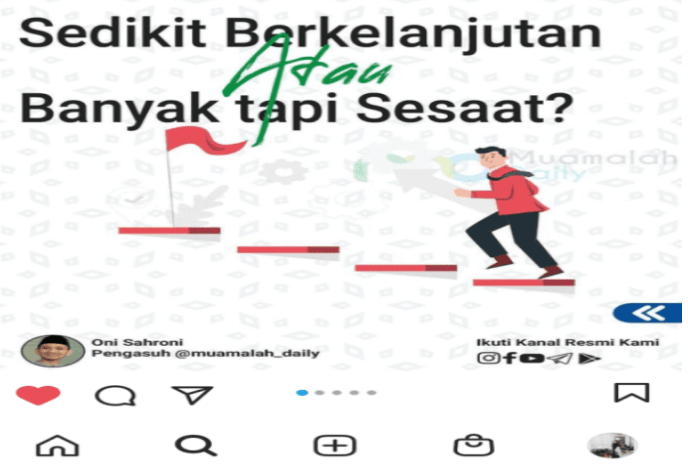

Live Konsultasi Syariah merupakan program yang membuka konsultasi syariah yang dilakukan secara langsung live instagram. Pada saat live, para pengikut dapat memanfaatkan kesempatan ini untuk bisa berdialog interaktif langsung dengan Oni Syahroni. Biasanya sebelum live konsultasi, jadwal 
konsultasi akan disebarkan terlebih dahulu di akun instagramnya.

Gambar. 6: Program Live Konsultasi Syariah

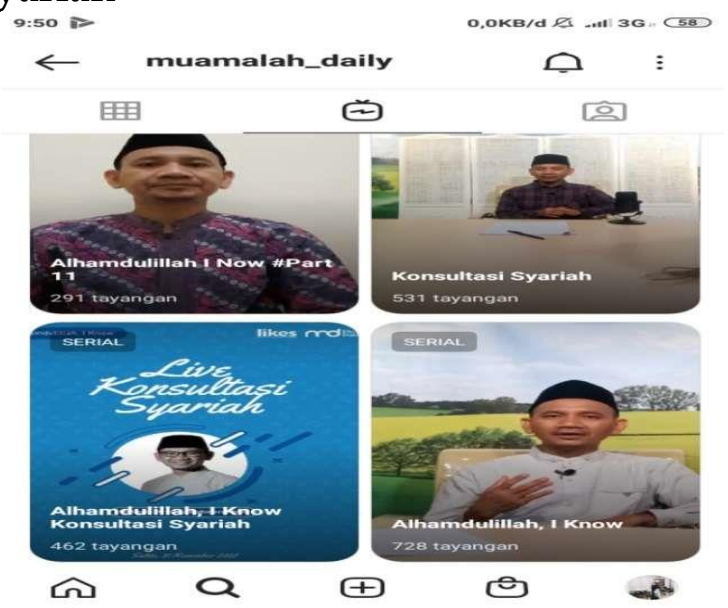

Tips Muamalah merupakan content yang membagikan tips untuk semakin optimal dalam menjalankan aktivitas muamalah ke depannya. Dalam hal ini, Oni memberikan panduan-panduan dan langkah-langkah strategis bagi pengikut untuk bisa bermuamalah dengan baik. Content ini ditampilkan dengan sangat menarik karena gambar sesuai dengan tema yang diangkat, sehingga pengikut mudah memahami dan menikmati dengan baik.

\section{Gambar. 7: Program Tips Muamalah}

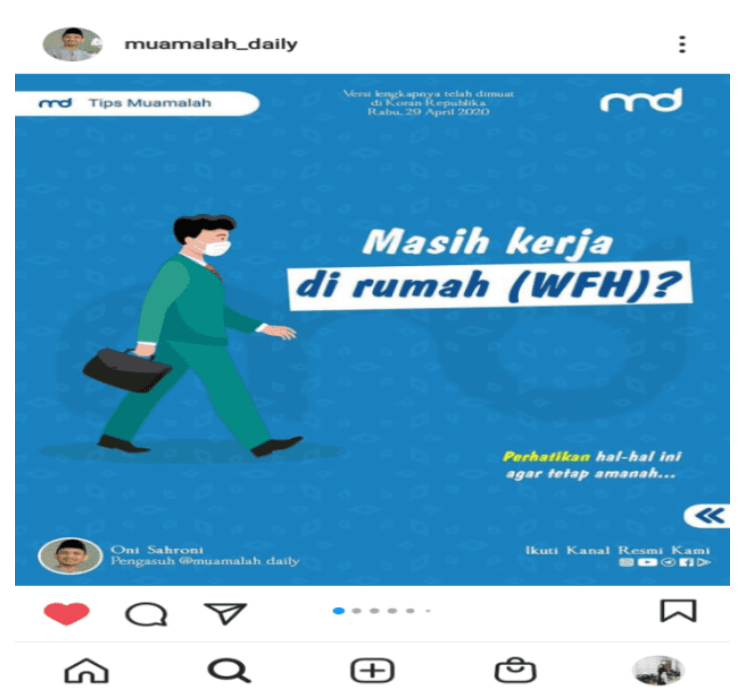

Kata Ustadz merupakan program yang mengutip sebagian kecil dari tulisan yang pernah dipublikasi oleh Oni Syahroni. Program ini berisikan penjelasan-penjelasan singkat tentang persoalan-persoalan muamalah, terutama muamalah kontemporer.

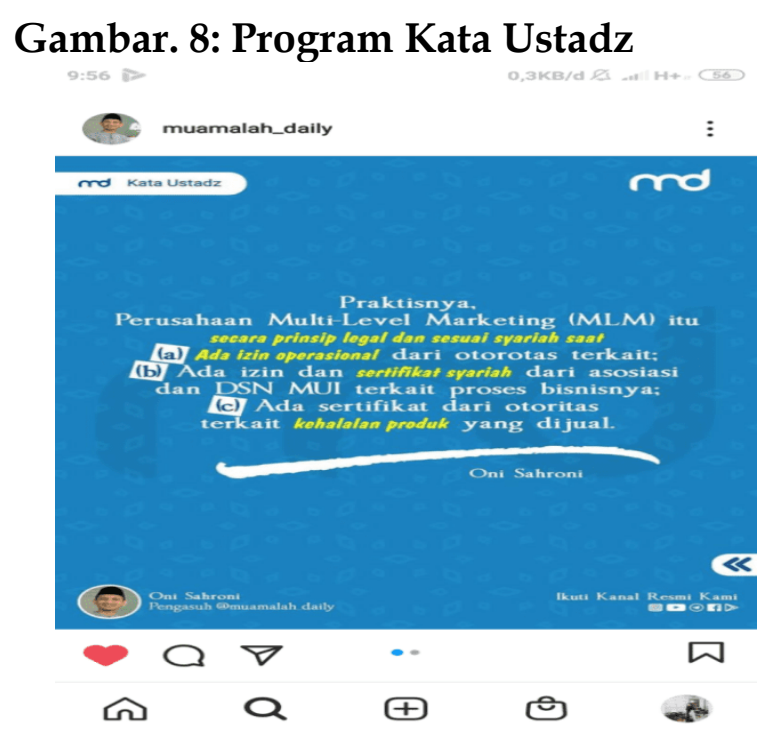

1 Minute Booster merupakan content yang menjelaskan konsep muamalah dalam bentuk video berdurasi 1 menit untuk memudahkan para pengikut dalam memahaminya. Video tersebut diisi langsung oleh suara Oni Syahroni.

\section{Gambar. 9: Program 1 Minute Booster}

9:56 is

$0,1 \mathrm{kB} / \mathrm{d} \& \mathrm{~s}$.

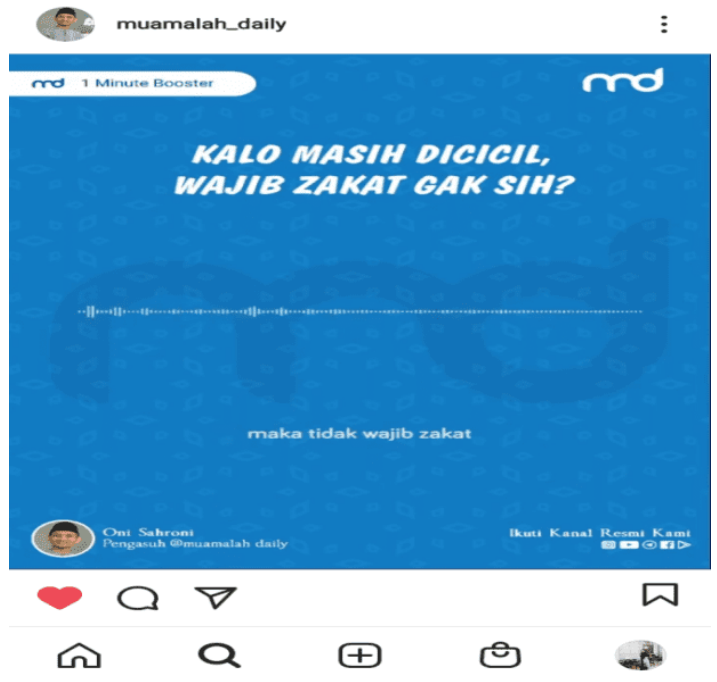


Alhamdulillah I Know merupakan content yang berisikan kutipan-kutipan naskah yang pernah ditulis maupun dipresentasikan oleh Oni Syahroni. Program ini juga berisikan persoalanpersoalan syariah teraktual.

\section{Gambar. 10: Program Alhamdulillah I} Know

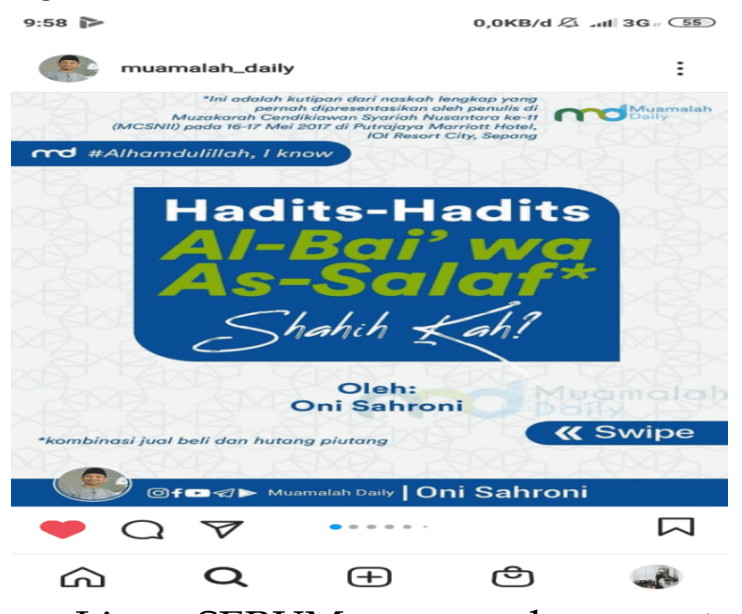

Live SERUM merupakan content yang berisi siaran langsung kajian yang diisi oleh Oni Syahroni bekerjasama dengan STEI SEBI. SERUM membahas tentang muamalah ala Rasulullah yang mana program ini dibagi ke dalam beberapa sesi. Setiap sesi disiarkan langsung di Instagram dan YouTube Muamalah Daily. Tujuan dari program ini adalah untuk menghidupkan sunnah Rasulullah.

\section{Gambar. 11: Program Live SERUM}

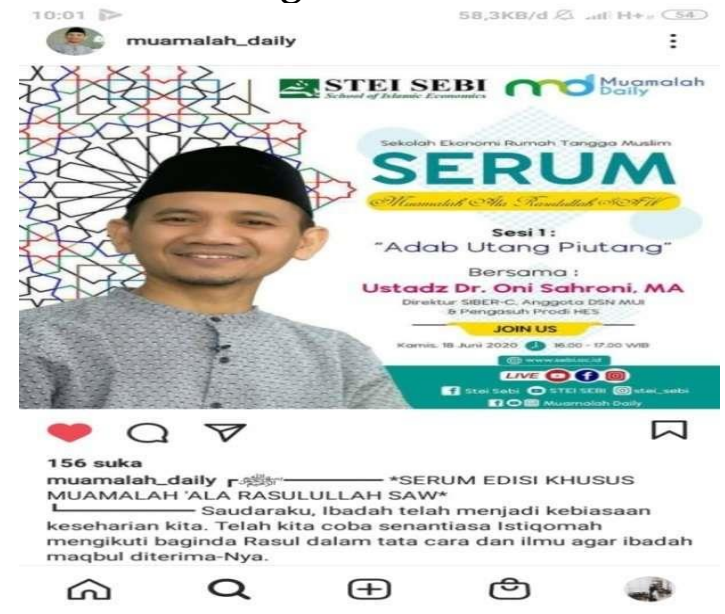

Bedah Fikih Kekinian merupakan program yang membedah fikih dan dalildalil tentang muamalah kekinian.

Gambar. 12: Program Bedah Fikih Kekinian

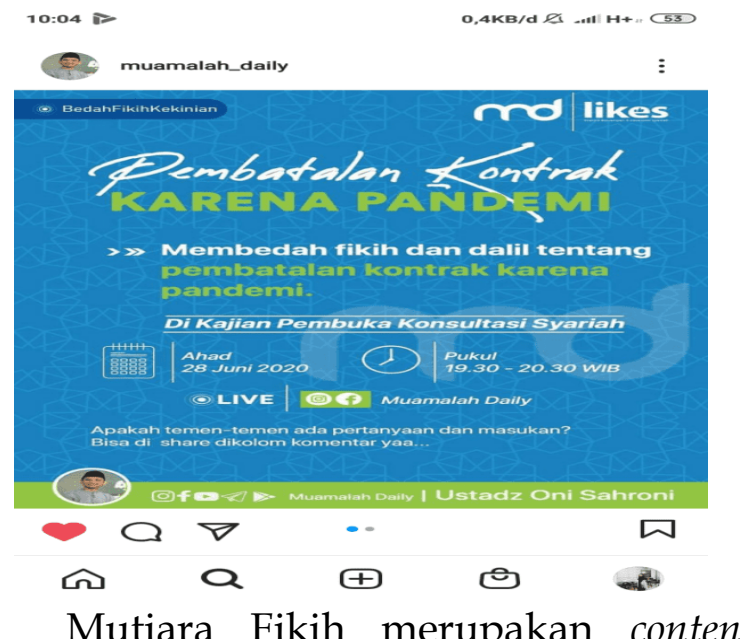
yang mengupas fikih lebih tuntas. Pada umumnya, content ini merupakan hasil dari tulisan Oni yang sudah diterbitkan di Koran Republika.

\section{Gambar. 13: Program Mutiara Fikih}

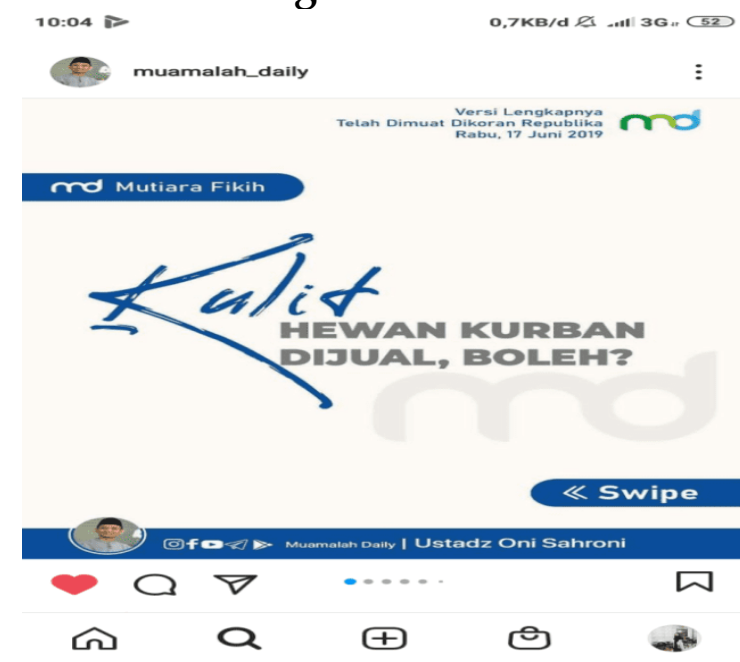

Serial Jawab Kuis merupakan content yang berisikan video tentang jawaban dan penjelasan terhadap pertanyaanpertanyaan dari kuis-kuis yang dibuka sebelumnya.

Gambar. 14: Program Serial Jawab Kuis 


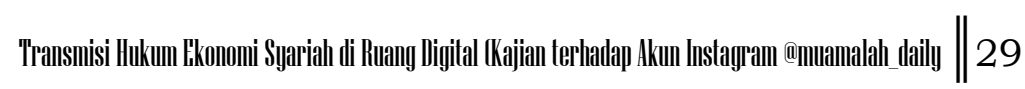

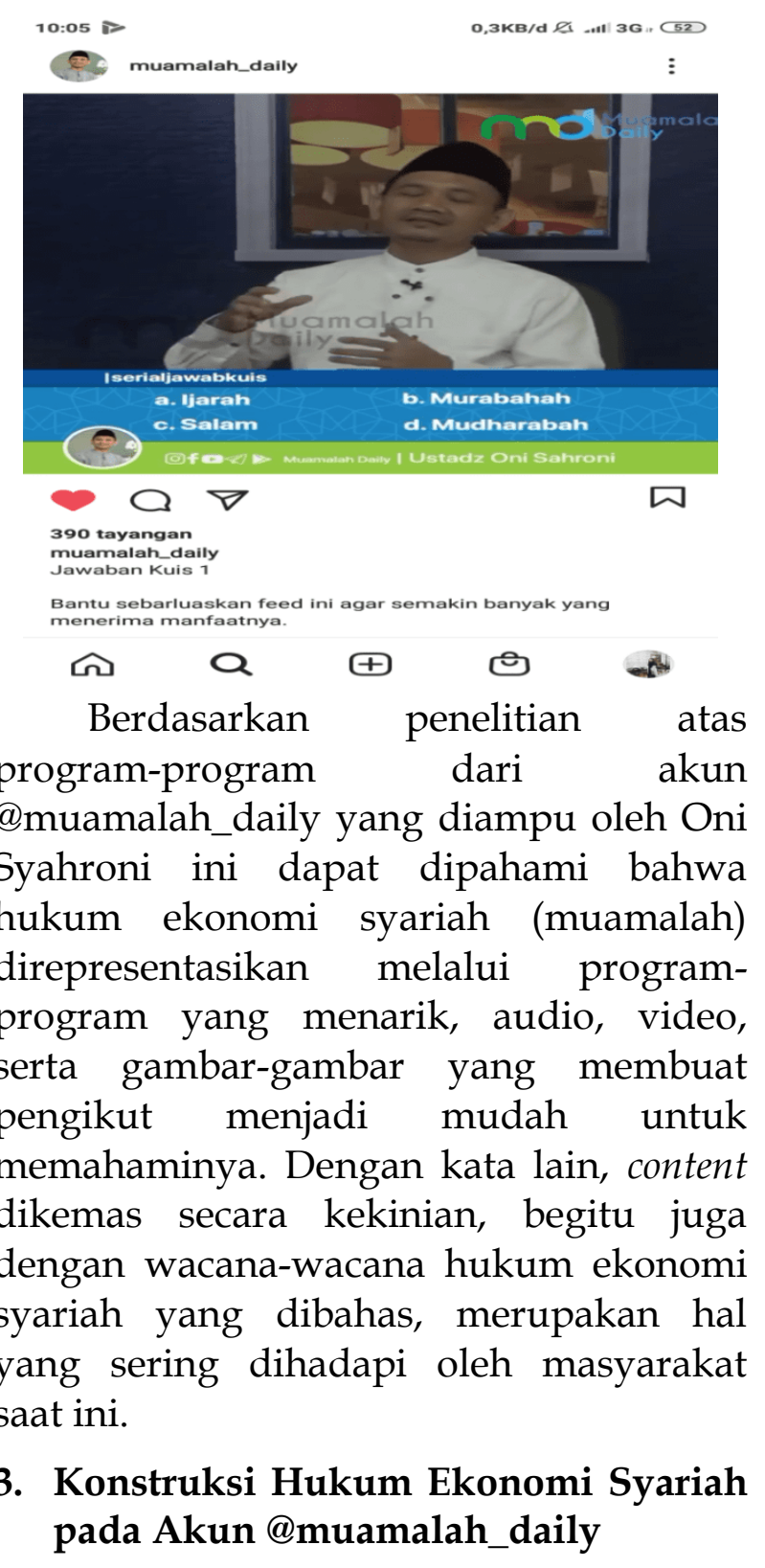

Dilihat dari pengikut akun @muamalah_daily yang mencapai 20,3 ribu, menunjukkan banyaknya peminat pengguna instagram terhadap akun ini. Setiap postingan@muamalah_daily mendapatkan banyak tanggapan positif dari para pengikutnya, baik dalam bentuk memberikan tanda suka maupun tanggapan pada komentar. Akun @muamalah_daily_membangun hubungan baik dengan para pengikutnya.
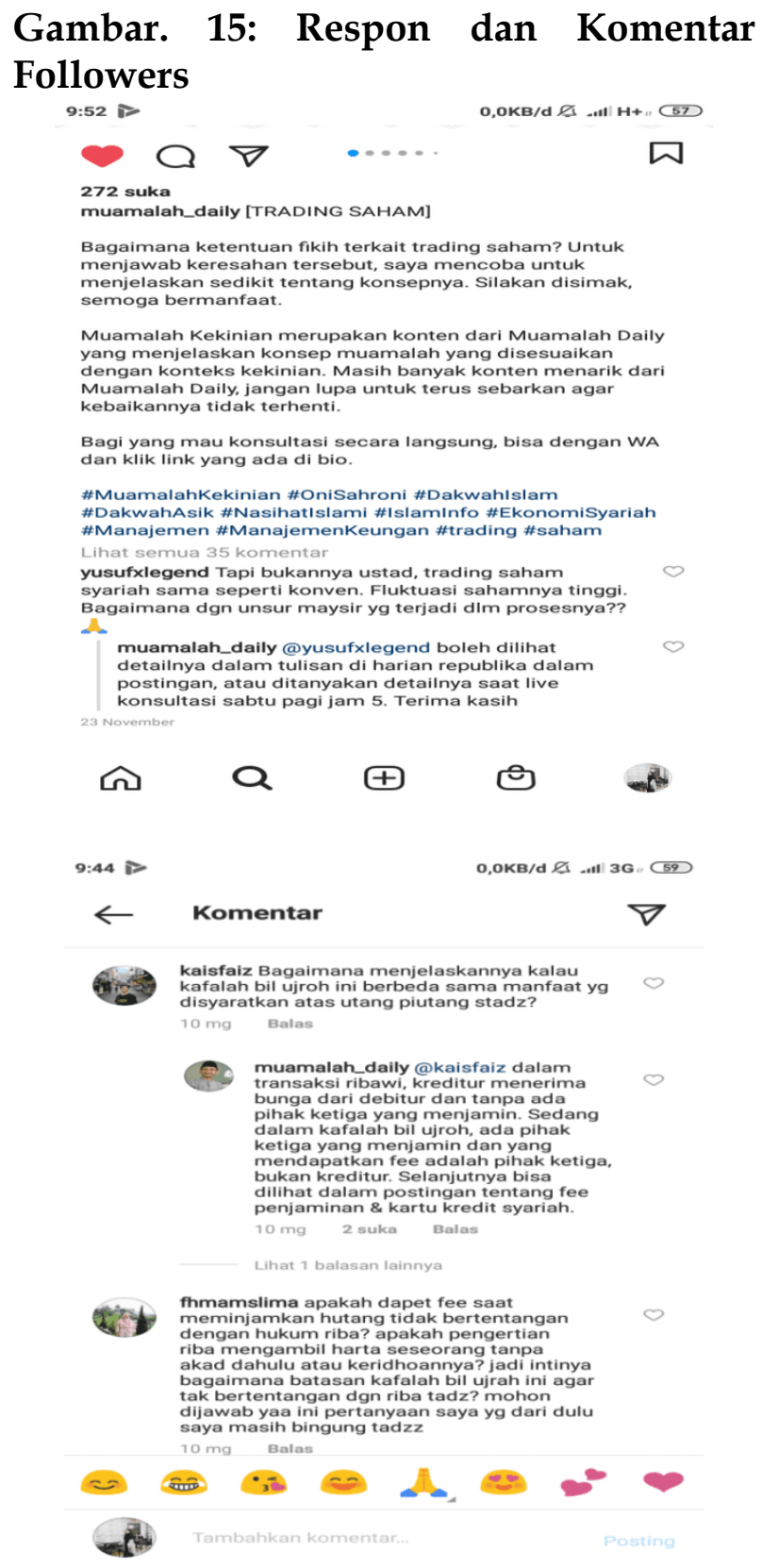

Dari sekian banyak postingan yang ditawarkan, yang membuat akun ini menarik adalah dengan adanya ruang konsultasi syariah dan muamalah. Akun @muamalah_daily membuka kesempatan kepada siapa saja yang ingin berpartisipasi dengan memberikan feedback secara terbuka, berupa komentar, dengan waktu yang cepat dan tidak terbatas. Para pengikutnya juga bisa berkonsultasi langsung lewat whatsapp 
pada link yang disediakan di profil instagram. Selain itu, akun @muamalah_daily menjalin kerjasama dengan lembaga-lembaga lain yang juga tertarik membahas seputar hukum ekonomi syariah, baik dalam bentuk live bersama di instagram maupun kegiatan seminar/kajian muamalah.

\section{Gambar. 16: Jadwal Live Konsultasi} Syariah

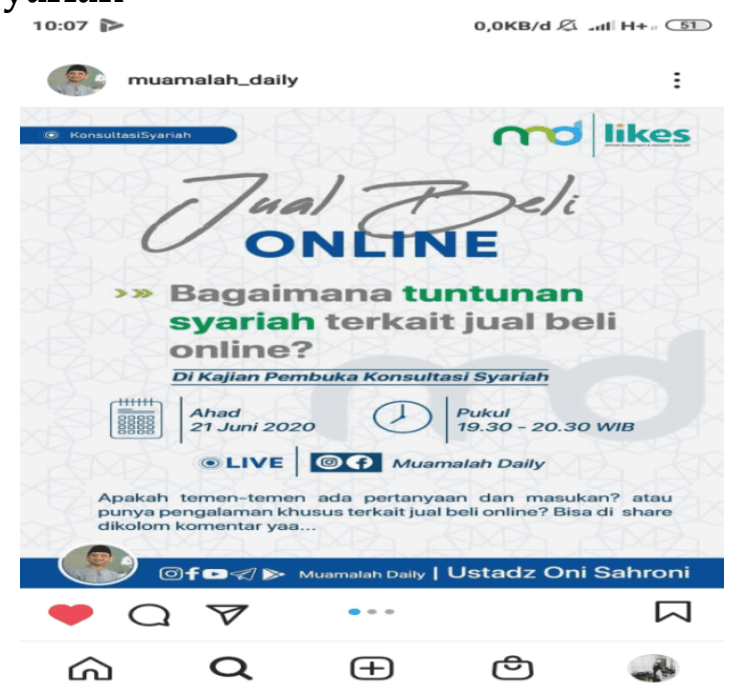

Akun ini menjadi media alternatif untuk mencari informasi seputar muamalah, baik oleh mahasiswa, tenaga pengajar, praktisi maupun masyarakat umum. Dengan kelebihan-kelebihan fitur yang disajikan instagram, memungkinkan akun @muamalah_daily mengembangkan konten dengan maksimal dan dengan model yang kreatif.

Pada akun @muamalah_daily para follower mendapatkan nilai estetika dan etika yang dipadu menjadi satu. Belajar fikih muamalah dibuat menjadi lebih asik dengan pemanfaatan fitur foto dan video. Secara umum, akun @muamalah_daily sudah efektif dalam pemenuhan kebutuhan informasi pengikutnya. Akun ini dijadikan rujukan dan referensi bagi followersnya, khususnya dalam hal-hal yang berkaitan dengan fikih muamalah kontemporer. Hal ini sejalan dengan pengamatan Arifki, bahwa setiap konstruksi wacana akan membentuk wacana dominan yang berkembang dalam masyarakat (Warman, 2017: 8). Akun ini juga fleksibel dalam menanggapi komentar dan pertanyaan-pertanyaan para pengikutnya.

Jika dilihat lebih rinci dari analisis pendekatan kebutuhan informasi, ditemukan beberapa hal: Dalam kacamata current need approach akun @muamalah_daily efektif dalam memberikan informasi terbaru mengenai hukum ekonomi syariah, terutama persoalan-persoalan kontemporer yang baru dalam masyarakat. Akun ini memberikan feedback dengan dijawabnya pertanyaan followers seputar syariah dan muamalah.

Untuk everyday need approach, dilihat dari informasi yang secara rutin dan jelas dibagikan oleh akun @muamalah_daily. Serta informasi-informai tersebut dapat dengan cepat dan mudah didapatkan bagi mereka yang ingin mengetahui seputar hukum ekonomi syariah.

Sementara jika dilihat dari exhaustic need approach, bisa dilihat pada komentar para followers di akun @muamalah_daily, mereka mendapat informasi yang bermanfaat, rasional dan mudah dipahami. Dan, akun @muamalah_daily juga memiliki kredibilitas terkait informasi yang diminta para follower, terlihat dari wawasan dan pemahaman yang diterima oleh para follower, serta informasi yang didapatkan relevan, spesifik juga lengkap.

Untuk catching-up need approach terlihat dari respon para follower terkait informasi yang singkat, padat dan jelas. Hal ini terlihat dari tanda suka dan 
komentar di akun instagram @muamalah_daily. Melihat respon di akun @muamalah_daily, menunjukkan daya tarik para follower terhadap akun tersebut, baik dari segi informasi, katakata maupun gambar yang dibagikan. Sehingga, para follower menyadari bahwa akun@muamalah_daily menjadi sumber informasi mereka seputar hukum ekonomi syariah. Dengan demikian, akun @muamalah_daily ikut mempengaruhi wacana hukum ekonomi syariah yang berkembang di masyarakat.

Selain itu, dilihat dari isi, wacana hukum ekonomi syariah dikonstruksi dengan mengedepankan aspek kontemporer. Dalam artian, Oni mencoba menjelaskan persoalan-persoalan muamalah yang sering dihadapi oleh masyarakat saati ini. Dalam menjelaskan persoalan tersebut, Oni tetap merujuk kepada al-Quran dan Hadis, serta fikih klasik tanpa meninggalkan aspek pembaharuan hukum. Dengan kata lain, akun@muamalah_daily@mencoba menjelaskan persoalan-persoalan muamalah kontemporer dengan menggunakan metode kontekstual. Kontruksi inilah kemudian menjadi hal yang menarik bagi pengikut untuk mengetahui lebih dalam persoalan muamalah. Transmisi pengetahuan hukum ekonomi syariah kontemporer pun berjalan dengan baik melalui akun instagram ini.

\section{KESIMPULAN}

Berdasarkan hasil penelitian yang penulis lakukan, dapat disimpulkan bahwa akun instagram @muamalah_daily ikut berperan sebagai media transmisi hukum ekonomi syariah. Akun ini menjadi media alternatif untuk mencari informasi seputar muamalah. Akun @muamalah_daily tidak hanya sekedar berbagi informasi seputar hukum ekonomi syariah, melainkan juga membuka konsultasi syariah dan muamalah bagi masyarakat yang ingin berkonsultasi langsung. Selain itu, akun @muamalah_daily juga acap kali mengadakan siaran langsung interaktif dengan followersnya. Dalam merepresentasikan hukum ekonomi syariah, akun ini menawarkan beberapa program yang bisa dimanfaatkan oleh para pengikutnya. Umumnya, konten yang diposting didominasi oleh fikih muamalah kontemporer, dengan merujuk kepada konsep dasar fikih klasik. Di antara programnya adalah Muamalah Kekinian, Bedah Istilah, Quiz Fikih, Ini Dulu Baru Itu, Live Konsultasi Syariah, Tips Muamalah, Kata Ustadz, 1 Minute Booster, Alhamdulillah I Know, Live SERUM (Sekolah Ekonomi Rumah Tangga Muslim), Bedah Fikih Kekinian, Mutiara Fikih, dan Serial Jawab Kuis. Dalam penyajiannya, wacana hukum ekonomi syariah kontemporer tersebut dikonstruksi dengan bahasa yang ringan, rasional dan mudah dipahami oleh masyarakat, serta dikemas dengan tampilan menarik. Akun @muamalah_daily menyajikan informasi terbaru mengenai hukum ekonomi syariah kontemporer, serta fleksibel dalam menanggapi komentar dan pertanyaanpertanyaan para pengikutnya. Akun @muamalah_daily memiliki daya tarik yang baik di mata para follower, baik dari segi informasi, kata-kata maupun gambar yang dibagikan. Para follower menyadari bahwa akun @muamalah_daily menjadi sumber informasi mereka seputar hukum 
ekonomi syariah. Dengan demikian, akun @muamalah_daily ikut mempengaruhi wacana hukum ekonomi syariah yang berkembang di masyarakat.

\section{DAFTAR PUSTAKA}

Aditya, R. (2015). Pengaruh Media Sosial Instagram terhadap Minat Fotografi pada Komunitas Fotografi Pekanbaru. Jom FISIP, 2(2), 1-14.

Agustina. (2016). Analisis Penggunaan Media Sosial Instagram Terhadap Sikap Konsumerisme Remaja Di Sma Negeri 3 Samarinda. eJournal Ilmu Komunikasi, 4(3), 404-405.

Arifin, F. N. (2015). Efektivitas Akun Instagram @Filmnasional Dalam Pemenuhan Kebutuhan Informasi Followers. E-Proceeding of Management, 2(3), 3971-3976.

Dahlan, M. (2020). Geneologi Islamisme di Kalangan Muslim Millenial Indonesia. El-Afkar: Jurnal Pemikiran Keislaman Dan Tafsir Hadis, 9(1), 1-25. https://doi.org/10.29300/jpkth.v9i1. 3234

Eriyanto. (2001). Analisis Wacana: Pengantar Analisis Teks Media. LKiS.

Ferlitasari, R. (2018). Pengaruh Media Sosial Instagram Terhadap Perilaku Keagamaan Remaja. Skripsi UIN Sunan Kalijaga.

Haryanto, H. (2016). Pemanfaatan Media Sosial Sebagai Media Komunikasi Komunitas Pustakawan Homogen Dalam Rangka Pemanfaatan Bersama Koleksi Antar Perguruan Tinggi. Edulib, 5(1), 83-89. https://doi.org/10.17509/edulib.v5i1 .2305
Helen, H., \& Rusdi, F. (2019). Pengaruh Penggunaan Media Sosial Akun Instagram @Jktinfo Terhadap Pemenuhan Kebutuhan Informasi Followers. Prologia, 2(2), 355-362. https://doi.org/10.24912/pr.v2i2.371 2

Makhin, A. (2016). Pengaruh Akun Instagram Javafoodie terhadap Minat Beli Konsumen. Skripsi UIN Sunan Kalijaga Yogyakarta.

Nasrullah, R. (2015). Media Sosial: Perspektif Komunikasi, Budaya dan Sosioteknologi. Simbiosa Rekatama Media.

Nisa, E. F. (2018). Creative and Lucrative Dawa: The Visual Culture of Instagram amongst Female Muslim Youth in Indonesia. Asiascape: Digital Asia, 5(1-2), 68-89. https://doi.org/10.1163/2214231212340085

Sari, P. (2017). Fenomena Penggunaan Media Sosial Instagram Sebagai Komunikasi Pembelajaran Agama Islam Oleh Mahasiswa Fisip Universitas Riau. Jom, 4(2), 1-13.

Sesriyani, L., \& Sukmawati, N. N. (2019). Analisis Penggunaan Instagram Sebagai Media Pembelajaran Bahasa Inggris Pada Program Studi Pendidikan Ekonomi. EDUKA : Jurnal Pendidikan, Hukum, Dan Bisnis, 4(1).

https://doi.org/10.32493/eduka.v4i1 .3822

Tim Penyusun Humas Kementerian Perdagangan RI. (2014). Panduan Optimalisasi Media Sosial untuk Kementrian Perdagangan RI. Pusat Humas Kementrian Perdagangan RI. 
Warman, A. B. (2017). Konservatisme Fikih Keluarga (Kajian Terhadap Buku-Buku Populer Rumah Tangga Islami). Tesis Magister UIN Sunan Kalijaga Yogyakarta.

Zahara, M. N., Wlidan, D., \& Komariah, S. (2020). Gerakan Hijrah: Pencarian Identitas Untuk Muslim Milenial di Era Digital. Indonesian Journal of Sociology, Education, and Development, 2(1), 58-70.

\section{Internet}

Adalah.Co.Id. (2019). “Instagram Adalah: Sejarah, Fungsi dan Keistimewaan Instagram", dari https://adalah.co.id.

Andi.Link. (2020). "Hootsuite (We are Social): Indonesian Digital Report 2020", dari https://andi.link.

Databoks. (2020). “Pengguna Smartphone diperkirakan Mencapai $89 \%$ Populasi pada 2025", dari https://databoks.katadata.co.id.

GoodNews From Indonesia. (2020). “Pengguna Instagram di Indonesia Didominasi Wanita dan Generasi Milenial", dari https://www.goodnewsfromindone sia.id.

https://www.instagram.com/muamalah daily/

Lokadata (2019). "10 Negara dengan Pengguna Instagram Terbanyak", dari https://lokadata.beritagar.id. 